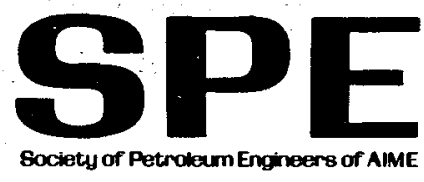

\title{
Seeking Prospects for Enhanced Gas Recovery
}

by Mark G. Doherty and Philip L. Randolph, Inst. of Gas Technology

Members SPE

\section{MOTICE PORTIOHS OF THIS REPORT ARE ILLEGIBLE. It has been reproduced from the thest availabile copy to permit the broadest}

CONF $-820927--8$

Copyright 1982. Society of Petroleum Engineers of AIME

This paper was presented at the 57th Annual Fall Technical Conference and Exhibition of the Society of Petroleum Engineers of AIME, held in New Orleans, LA, Sept. 26-29, 1982. The material is subject to correction by the author. Permission to copy is restricted to an abstract of not more than 300 words. Write: 6200 N. Central Expressway, P.O. Drawer 64706, Dallas, Texas 75206.

\section{ABSTRACT}

As part of the Institute of Gas Technology's (IGT) ongoing research on unconventional natural gas sources, a methodology to locate gas wells that had watered-out under over-pressured conditions was developed and implemented. Each year several trillion cubic feet (Tcf) of gas are produced from reservcire that are basically geopressured aquifers with large gas caps. As the gas is produced, the gas-water interface moves upward in the sandstone body trapping a portion of gas at the producing reservoir pressure. The methodology for identifying such formations consisted of a computer search of a large data base using a series of screening criteria to select or refect wells. The screening criteria consisted of depth cutoff, minimum production volume, minimum pressure gradient, and minimum water production. Wells chosen by the computer search were further screened manually to seek out those wells that exhibited rapid and large increases in water production with an associated quick decline in gas production indicating possible imbibition trapping of gas. in the reservoir.

The search was performed in an attempt to characterize the watered-out geopressured gas cap resource. Over 475 wells in the Gulf Coast area of Loulsiana and Texas were identifled as possible candidates representing an estimated potential of up to about $1 \mathrm{Tcf}$ $\left(2.83 \times 10^{10} \mathrm{~m}^{3}\right)$ of gas production through enhanced recovery operations. In addition, several thousand wells appeared to have watered-out but not at high enough pressures or with what was considered a strong enough water drive. Furthermore, many thousands of normally pressured shallow gas reservoirs were eliminated by the first screen and no production history obtained. This implies that the potential resource base for enhanced gas recovery is substantially greater.

A process to determine the sultability of a watered-out geopressured gas cap reservoir for application of enhanced recovery is outlined.: Working from data available in the public domain this, pracess was applied to ascertain the potential and risk involved in enhanced recovery for over .50 wells. It also was used to determine which ones appeared to be the better prospects.
This paper addresses the identification of a potential gas source that is considered an unconventional resource. The methodology developed to identify watered-out geopressured gas cap wells can be utilized in seeking other types of watered-out gas reservoirs with the appropriate changes in the screening criteria. ( 2 figures, 5 tables, 12 refs.)

\section{INTRODUCTION}

A fraction of geopressured aquifers in the Gulf Coast are accompanied by gas caps. When tapped by conventional techniques these caps are prolific gas producers. Such wells produce several Tcf of gas per year domestically. As the natural gas is produced, the gas-water interface moves upward in the sandstone body. - During this water invasion, a sizeable amount of gas is left behind trapped in the pore space of the reservoir. The remaining gas fills an estimated $15 \%$ to $50 \%$ of the pore volume originally occupied by the gas at the producing pressure. ${ }^{1-2}$ In addition, when gas wells "water out" natural gas updip from the perforated intervals of the wells remains trapped as "attic gas" at the original position in the gas caps.

Transcontinental Pipeline Company (Transco) made public information about a potent lal process to enhance the recovery of this trapped gas by highvolume water production from the original formation. 3-6 Computer simulation showed that high-volume water production could recover additional billions of cubic feet (BCf) of gas before the gas-water ratio (GWR) would again decline to that characteristic of a watered-out reservoir.

As part of IGT's ongoing research on unconventional natural gas sources funded by the Gas Research Institute (GRI), a methodology to identify gas wells that had watered-out under overpressured conditions was developed and implemented. While a considerable research effort has been sponsored by the Department of Energy (DOE) to examine the possibility of tapping the enormous gas resource associated with geopressured aquifers, little work had been performed in the public domain on the identification of the potential for enhanced recovery of watered-out geopressured gas caps. 


\section{DISCLAIMER}

This report was prepared as an account of work sponsored by an agency of the United States Government. Neither the United States Government nor any agency Thereof, nor any of their employees, makes any warranty, express or implied, or assumes any legal liability or responsibility for the accuracy, completeness, or usefulness of any information, apparatus, product, or process disclosed, or represents that its use would not infringe privately owned rights. Reference herein to any specific commercial product, process, or service by trade name, trademark, manufacturer, or otherwise does not necessarily constitute or imply its endorsement, recommendation, or favoring by the United States Government or any agency thereof. The views and opinions of authors expressed herein do not necessarily state or reflect those of the United States Government or any agency thereof. 


\section{DISCLAIMER}

Portions of this document may be illegible in electronic image products. Images are produced from the best available original document. 
Using publically available information and targeting the Gulf Coast area, the IGT effort was directed at examining whether there were opportunities for enhanced gas recovery operations, identifying specific production horizons as candidates for possible enhanced recovery, qualifying and selecting those prospects that appeared to be the preferred sites for proof-of-concept demonstrations, and developing the appropriate research to implement field operations in order to provide the industry with suffllent information homake informed

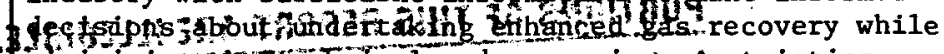
- inimizing tre techn cal and efgonomfetingertainties.

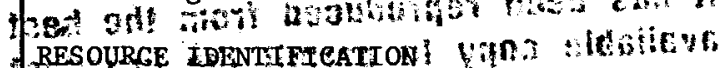

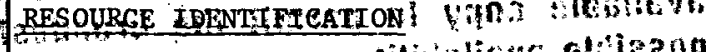

The search for watered-out geopressured gas cap wells began by contacting a number of organizations to determine the data bases available. After discussions with the various groups, IGT concluded that Petroleum Information (PI) of Denver appeared to have the detailed data required and the means to provide the output tailored to our specific needs. Rather than immediately searching the entire Gulf coast region, IGT decided to test two small areas in Louisiana where watered-out geopressured gas cap wells were known to exist. This test provided IGT and PI with the necessary operating experience to screen well data and to selectively eliminate as many as possible of the wells. To further minimize the amount and the cost of data generated, some initial screening criteria on depth, pressure, and production were developed to restrict the selection of the potential wells. The top of the geopressured zone was the first cutoff. Any well deeper than 12,000 feet $(3658 \mathrm{~m})$ in the test areas would pass on to the next criteria, which required it to have an original pressure gradient greater than $0.75 \mathrm{psi} / \mathrm{ft}$ $(17.0 \mathrm{k} \mathrm{Pa} / \mathrm{m})$ of depth and a final pressure gradient greater than $0.50 \mathrm{psi} / \mathrm{ft}(11.3 \mathrm{k} \mathrm{Pa} / \mathrm{m})$ of depth. Because a well must be a large producer to possibly be economically attractive as well as provide sufficient data for reservoir engineering analysis, the final criterion was that a well must have produced in excess of $1 \mathrm{Bcf}\left(2.83 \times 10^{7} \mathrm{~m}^{3}\right)$ but not be producing now from the horizon(s) screened. Table 1 summarizes these criteria for well selection in the test areas.

From a theoretical perspective these screens would provide a subset of wells with their respective production test data that could be examined manually for large, rapid increases in water output accompanied by sharp declines in gas production. Wells fitting this description would be considered likely candidates as watered-out geopressured gas caps where quantities of gas were possibly trapped by the water invasion. The production test data reports or gas deliverability test were chosen because thoy contained information on water production and pressures as well as hydrocarbon production.

However, the experience gained from screening the wells in the test areas required that a somewhat different approach be employed. This was because the production test data often did not contain shut-in wellhead pressures on which to estimate the initial and final pressure gradients for comparisons against the screening criteria. As a result, a somewhat different methodology was adopted and is illustrated in Figure 1.

Information from PI's production history and well control data bases were merged to begin the process. The flrst screen was based on the minimum depth that a well would have to penetrate to be in the geopres- sured region. Each parish, county, or offshore area was assigned a depth cutoff based on the shallowest top of the geopressured zone in the specific area as indicated by the contour lines of Map 3 in U.S. Geological Survey Circular $790: 7$ The effect of this screen was to eliminate numerous shallow wells particularly in hydropressured formations.. Because the top of the geopressured zone did change by over 3,000 feet in many areas, some wells that were not geopres $\rightarrow$ sured often were included.

The decision to eliminate wells not in the geopressured zone was made with the knowledge that to produce large quantities of brine as cheaply as possible by natural flow and at rates reasonable enough to create the necessary pressure drop in the reservoir as described by Cook and Geer in their patents ${ }^{3-5}$ a well needs to be overpressured when it watered-out. This infers that the reservoir had to have had a very high-pressure gradient with which to start. If the pressure in the well at watering-out were only about hydrostatic, sufficient water flow could be accomplished only by artificial lift thereby adding significant costs to the project. Thus, the screen to seek wells in the reopressured zone was established. The effect was to reduce by $50 \%$ the 100,000 plus number of wells that began the screening process.

The second criterion examined the remaining wells for cumulative production. If gas production exceeded 1 Bcf $\left(2.83 \times 10^{7} \mathrm{~m}^{3}\right)$, the well was retained; otherwise it was rejected. The I Bcf $\left(2.83 \times 10^{7} \mathrm{~m}^{3}\right)$ cut-off was used to identify a well that was large gas producer, which is necessary to assure that enough recoverable gas is trapped in the reservoir to justify the additional expense of enhanced recovery. But, perhaps, more important is what the $1 \mathrm{Bcf}\left(2.83 \times 10^{7} \mathrm{~m}^{3}\right)$ represents in terms of providing a basis for a reservoir engineering assessment of the formation. When reduced to reservoir conditions, 1 Bcf $\left(2.83 \times 10^{7} \mathrm{~m}^{3}\right)$ of gas is equivalent to the removal of about 200,000 barrels $\left(31800 \mathrm{~m}^{3}\right)$ of brine from a geopressured aquifer. This volume of fluid production from a formation when coupled with other reservoir data provides a basis for determining reservoir limits, matching production and pressure histories, and establishing reservoir conditions at the time of watering-out. This screen reduced the remaining number of wells by about $60 \%$ to 20,000 .

of the wells remaining after the first two screens (amounting to about $20 \%$ of the original number), approximately half had shut-in surface pressure readings. In addition, some wells did not have shut-in wellhead pressures at the end of their productive lives. Furthermore, a technique to calculate bottomhole pressures from the production test data for two or three phases is a complicated undertaking in itself, let alone compounding this matter with the manipulation of a complex and massive computerized data base. Thus, to avoid the unnecessary elimination of wells, the original shut-in pressures where available which were considered to represent reasonably good data were used with a simplified calculation based on the reported gas gravity to determine the original bottomhole pressure and pressure gradient. Wells with original bottomhole pressure gradients equal to or greater than $0.65 \mathrm{psi} / \mathrm{ft}$ $(14.7 \mathrm{k} \mathrm{Pa} / \mathrm{m})$ were retained for further screening. This group represented about $2 \%$ of the total number of wells screened or 2,000 wells. 
Wells that lacked shut-in surface pressure data were screened for water production. An examination of a number of these wells before the final computer runs led to the conclusion that a large percentage of them had little if any water production. That is, they were depletion-drive rather than water-drive reservoirs. Since strong enough water drive is needed to trap the gas in the reservoir by imbibition and to cause the wells to water-out rapidly, a 100 barrel per day (bpd, $15.9 \mathrm{~m}^{3} / \mathrm{d}$ ) water production rate was set as a screen. of the wells screened in this set, about $1 \%$ of the orlginal total number or 1,000 wells met this criteria.

The next step was to manually examine the computer printouts of the 3,000 retained wells to determine those that exhibited a rapid increase in water production with a corresponding sharp decrease in gas production. This final step identified 489 wells that appeared to have watered-out in a way consistent with trapping of gas by water invasion during production. Checks against some proprietary data indicated a match on many of the flelds, producing horizons, and wells. From other information available publicly, the computer-manual search methodclogy turned up wells in fields that were known to have watered-out in the prescribed manner, but that were normally pressured rather than geopressured. This apparent discrepancy was due to a lack of reported shut-in surface pressure measurements. The methodology appeared to have functioned properly even though the data base at times did not contain some key elements.

In terms of this very limited resource under consideration, an interpretation of the potential magnitude is subject to numerous constraints and assumptions. The 489 wells identified in the printouts had produced a total of 4.2 Tcf $\left(1.2 \times 10^{11} \mathrm{~m}^{3}\right)$. Computer simulations have shown that an additional 10 to 20 percent of the already produced volume may be extracted from watered-out geopressured gas cap wells. This would Imply that these wells could represent about .42 to $.84 \mathrm{Tcf}\left(1.2\right.$ to $\left.2.4 \times 10^{10^{3}} \mathrm{~m}^{3}\right)$ in additional production. However, this estimate should be tempered by a number of points:

Only wells classifled as gas wells by state regulatory authorities were screened. No associated gas was included.

Neither Texas or Louisiana state waters nor the Loulsiana Federal offshore area was included in the search due to funding limitations.

This project by no means has identified all watered-out geopressured gas cap wells due to missing, non-existent or incorrect data.

A large number of the wells lacked data on shut-in pressures or barely missed the pressure gradient cutoff. Where shut-in surface pressure data were avallable only wells with relatively high initial pressure gradients of $0.65 \mathrm{psi} / \mathrm{ft}(14.7 \mathrm{k} \mathrm{Pa} / \mathrm{m})$ or greater were retained.

- The production test data used for this study are limited to information on tests performed from about 1965 through 1979.

- This resource is continuously changing as additional gas wells water-out under overpres. sured conditions.
Even with the above constraints and assumptions on the resource estimate, there 16 a practical consideration for the production of gas from watered-out geopressured gas caps. From the prospective of the operator, one possibly can, for a marginal cost, increase the cumulative production from a well. At this time, however, the risk of attempting the production of gas trapped by imbibition in a watered-out geopressured gas cap is great for operators. While there have been some laboratory research and computer simulations, there has been no field demonstration on which to base the risk and returns for producing from watered-out geopressured gas caps. Thus, the economic viability and technical practicality of such an endeavor need to be proven before operators can be expected to undertake enhanced gas recovery operations for the deeper, watered-out geopressured gas caps.

\section{RESERVOIR IDENTIFICATION}

Having established a 1ist of 489 wells that appear ed to be reasonable candidates, the next step was to identify the preferred locations for a possible field demonstration. A review of the wells grouped by flelds pointed out an interesting fact that about one-third of the wells previously identifled were located in 46 fields with the remaining wells in about 300 fields. Tables 2 and 3 list those flelds in Loutsiana and Texas, respectively, in which the screening process identified three or more possible watered-out geopressured gas cap wells. In particular, two Texas fields, Alazan North and Katy, are known to be normally pressured and were included because the screening process did not eliminate them due to a lack of reported shut-in pressures.

A detailed examination of the production test date of 489 selected wells led us to $s p 1$ it the wells into two basic groups. About half the wells whose test Information showed greater and faster increases in water production with corresponding quicker and steeper declines in hydrocarbon volumes were categorized as Group I; the remainder were 1isted in Group II. This hueristic approach was required to narrow the number of wells to investigate.

To further shrink the number of wells, Eaton Operating Company (EOC) reviewed the list of fields and Indicated the ones that were in a water or swamp location. ${ }^{8}$ This was done on the basis that an enhanced gas recovery undertaking was a $x$ lsky enough venture without substantially increasing costs due to the use of barge mounted equipment.

Discussions with personnel at the Louisiana Department of Natural Resources and the Rallroad Commission of Texas indicated that while substantial information was recorded, data prior to 1970 would require a great deal of time to locate. In addition, changes in the reporting forms and regulations over time further complicated the collection of data. Thus, "older" wells were dropped from immediate consideration.

\section{PROSPECT QUALIFICATION}

This process of elimination narrowed the number of Group I wells to 54 in Louisiana and 57 in Texas. With a reasonable size set of wells to examine, certain functions must be performed to determine the feasibility of a reservolr for enhanced gas recovery. To be useful to the industry, the activities leading to a field operation need to focus on qualifying a 
prospect for enhanced gas recovery and must be carried out in such a way to provide sufficient information and the rationale to make informed judgments and decisions which can be applicable to other formations of interest to producers and purchasers of the gas. To this extent, Figure 2 illustrates a flow of activities to determine the suitability of a prospect for enhanced recovery from the perspective of a research group examining a large number of prospects.

Figure 2 begins by narrowing the 1ist of prospects. Production histories and the results of gas deliverability tests are needed to establish the condition of the reservoir at the time the well watered-out. Records in the public domain provide an insight into this situation, but may not be sufficient to make a defensible conclusion to reject or continue with a prospect. At this point, interaction with the operator of the well may be required to decide to what extent a well was overpressured when it watered-out.

This study concentrated on wells that watered-out with relatively high bottomhole pressures. As such, only wells with a $0.6 \mathrm{psi} / \mathrm{ft}(13.6 \mathrm{k} \mathrm{Pa} / \mathrm{m})$ or greater pressure gradient at the time of watering-out will be accepted. While this criterion may be subject to some adjustment, a formation must be able to produce substantial quantities of water in order to drop the reservoir pressure. With too low a pressure gradient, the additional expense of artifical lift must be incorporated.

Next, a reservoir analysis begins by assembling comprehensive data on the parameters essential for computerized reservoir simulation. At this time, the level of interest on the part of the operator can be assessed. Should the operator not be willing to proceed, the well is eliminated. Working closely with the operator the computer simulation parameters can be determined and reasonable engineering estimates developed for those not readily available.

A reservoir simulation to obtain a history match for fluids production and pressure then is run. If a good match is not obtained, the advice of relevant experts may be required to make a history match without significantly altering parameters thought to be reliably determined. On the other hand, the computer simulation may lead us to question various engineering assessments already made.

Once a reasonable history match has been obtained, projected fluids production using wellhead control is simulated. The simulation is used to establish the producing criteria to see an increasing gas water ratio or gas "kickoff." A time perlod for this gas kickoff must be selected that is compatible with the project economics and acceptable level of risk. A 30 to 60 day period is suggested, with a shorter period of time preferable. The well design (i.e., production tubing diameter) necessary to achieve the desired gas kickoff may not be usable in the well under study. The well can be rejected, or filed away for possible future consideration when the technical aspects and economics may be more attractive.

A well and reservoir that appear to have potential as a trapped gas producer must be evaluated for the down-side risk by examining worst-case reservoir parameters and determining what the outcome might be for an operator. Possible poor reservoir performance must be considered when assessing a prospect.
Reservoirs that are still acceptable are passed on to the next phase. Cost estimates to conduct a test or operation of the specific well and reservoir must be developed. Knowledge of the reservoir potential, the down-side risk, and the cost of the operation are required to allow a producer to make an informed decision about a prospect.

To move forward with this process, IGT obtained PI Production Summary Reports for the remaining 54 Group I Louisiana wells. (The Bureau of Economic Geology of the University of Texas at Austin were investigating Texas prospects.) Using these test and cumulative production data in conjunction with a set of simplified algorithms to determine static and flowing bottomhole pressures (See Appendix), each well was examined to determine if it, had a sufficiently high enough pressure gradient. Those that had an estimated $0.6 \mathrm{psi} / \mathrm{ft}$ $(13.6 \mathrm{k} \mathrm{Pa} / \mathrm{m})$ pressure gradient at the time they watered-out were further scrutinized to estimate the aquifer size and amount of trapped gas.

Assuming a sealed system as with the highly faulted Gulf Coast area, the total water influx from the aquifer was estimated by the cumulative volumes of gas, condensate, and water produced where the gas volume was converted to reservoir conditions by:

$$
\begin{aligned}
& v_{g}(r s)= \\
& V_{g} \text { (surface) } \times 1000 \text { scf/Mcf } \times 14.73 \text { psia } \times 620^{\circ} \mathrm{R} \\
& 520 \mathrm{R} \times \mathrm{P}_{i} \times 5.6146 \mathrm{ft}^{3} / \mathrm{bbl} \\
& \text { where } \mathrm{V}_{\mathrm{g}} \text { (rs) = Reservoir barrels of gas } \\
& V_{g}(\text { surface })=\text { Volume of gas at surface condi- } \\
& \text { tions in Mcf } \\
& 14.73 \text { psia = Pressure base } \\
& 60^{\circ} \mathrm{F}=520^{\circ} \mathrm{R}=\text { Temperature base } \\
& 160^{\circ} \mathrm{F}=620^{\circ} \mathrm{R}=\text { Assumed gas temperature in reser - } \\
& \text { voir } \\
& P_{i}=\text { Initial (reported) reservoir pressure } \\
& \text { (psia). }
\end{aligned}
$$

where $P_{i}$ estimated by IGT algorithm using shut-in surface pressure or estimated from flowing pressure algorithm $+10 \%$ based on comparison of wells with both shut-in and flowing surface pressures.

The use of a high $P_{i}$ provides a relative conservative approach to estimate the reservoir volume that the gas occupied.

Assuming an average system compressibility

$\left(c_{e}\right)$ of $7 \times 10^{-6} \mathrm{psi}^{-1}$ the following equation relates the changes in the volume for the water influx and pressures to the total aquifer volume (V):

$$
\begin{aligned}
\mathrm{Ce} & =\Delta \mathrm{V} /(\mathrm{V} \Delta \mathrm{P}) \text { or } \\
\mathrm{V} & =\Delta \mathrm{V} /(\Delta \mathrm{P} \text { Ce })
\end{aligned}
$$

where $\Delta V=$ water influx just calculated $\left(V_{g}(r s)\right.$ plus condensate and water produced)

$$
\Delta P=\left(P_{1}-P_{f}\right)
$$

where $\mathrm{P}_{f}=$ final flowing BHP pressure, i.e., lowest value (psia) 
The total volume occupled by the formation is then equal to $\mathrm{V} / \phi$ where $\phi$ is assumed to be an average porosity of $0.25(25 \%)$. The volume of gas trapped is estimated assuming that $25 \%$ of the pore space is occupied by the gas at the last and lowest flowing bottomhole pressure (BHP) by:

Volume of trapped gas in Mcf at standard conditions $=$

$$
\frac{Q \times 5.61 \mathrm{ft}^{3} / \mathrm{bb} 1 \times\left(\mathrm{P}_{\mathrm{f}}\right) \times 520^{\circ} \mathrm{F} \times .25}{14.73 \times 620^{\circ} \mathrm{R} \times 1000 \mathrm{scf} / \mathrm{Mcf} \times .75}
$$

Adjusting for pressure, temperature, and pore space occupied by the gas and water and where $Q(=\Delta V)$ is the water Influx in barrels.

The implication of this approach in terms of formation size and gas trapped as well as the calculations for static BHP leads us to recommend that the ten fields in Louisiana listed on Table 4 be used as the basis to move forward with the qualification process if operator cooperation can be secured. Because of other groups work in Texas, only the Martin Ranch (Frio 14600) field was examined in this detail. The Martin Ranch field heads the list of Texas prospects on Table 5 . The other Texas fields listed on Table 5 were selected based on a comparison of well data from the computer screening process but require further data collection and analyses before proceeding with the qualification process.

\section{CONCLUSIONS}

The principal conclusions for this study are:

1. The investigation into the possibility of locating watered-out geopressured gas. caps by using a computerized screening process coupled with a manual examination of production test data indicated that there was a substantial number of potential prospects for enhanced gas recovery.

2. Based on this analysis, specific producing hortzons in the fields listed on Tables 4 and 5 appear to be good candidates for enhanced gas recovery.

3. The concepts of gas trapped by water invasion and enhanced gas recovery have been shown in the laboratory and by computer simulation. However, the technical and economic risks are st111 great because with the exception of some shallower normally pressured operations 9,10 enhanced gas recovery from deeper overpressured formations has yet to be demonstrated.

4. Until a well documented field test of a watered-out geopressured gas cap is undertaken, the capability to select a production horizon for enhanced gas recovery is based strictly on engineering estimates with relatively high levels of uncertainty associated with the analysis.

5. With adjustments to the computer screening criteria, a broader picture of the watered-out gas reservoir resource could be investigated.

6. The qualification of a prospect for enhanced gas recovery is important to minimize the risk to the operator. As enhanced gas recovery operational information becomes avallable, some simplication of the selection process is expected.

\section{ACKNOWLEDGEMENT}

The data and analysis reported in this paper were done so under GRI Contract No. 5011-310-0109. The work of Mr. Subrata Chowdhury of IGT for his efforts on data collection and analysis is acknowledged. We also appreciate the cooperation and efforts of Mr. Mark Weiss of PI for the implementation of the compute screening process and Mr. Dan Langford and Mr. Dion Cole of EOC for their assistance on identifying fields in poor locations for a field test.

\section{REFERENCES}

1. Geffen, T.M., Owens, W.W., Parrish, D.R. and Morse, R.A., "Experimental Investigation of Factors Affecting Laboratory Relative Permeability Measurements," Pet. Trans., AIME 192, 1951; pp. 99-110.

2. Geffen, T.M., Parrish, D.R., Haynes, G.W. and Morse, R.A., "Efficiency of Gas Displacement From Porous Media by Liquid Flooding," Pet. Trans., AIME 195, 1952, pp. 29-38

3. Cook, H.L. and Geer, E.C., "Method for Increasing the Recovery of Natural Gas From a Geo-pressured Aquifer," Patent Nos. 4,040,487 and 4,042,034 (1977) August.

4. Cook, H.L. and Geer, E.C., "Method for Increasing the Recovery of 011 and Gas From a Water Invaded Geo-pressured Water Drive Oil Reservoir," Patent No. 4,090, 564 (1978) May.

5. Cook, H.L. and Geer, E.C., "Method for Increasing the Recovery of $\mathrm{O} 1 \mathrm{l}$ and Gas From a Geo-pressured Aquifer," Patent No. 4,116,276 (1978) September.

6. Cook, H.L. and Geer, E.C., "Enhanced Gas Recovery From Geopressured Aquifers," SPE 7541, 53rd Annual Fall Technical Conference and Exhibition of SPE, Houston, Oct. 1978.

7. Muffler, L.J.P. et a1, "Assessment of Geotherma1 Resources of the United States - 1978," U.S. Geological Survey, Circular 790, 1979.

8. Langford, D.A., Monthly Letter Report for November 1981 to Institute of Gas Technology, Nov. 24,1981 .

9. Chesney, T.P., Lewis, R.C. and Trice, M.L., "Enhanced Gas Recovery from a Moderately Strong Water Drive Reservoir," Proceedings of the Fifth Geopressured-Geothermal Energy U.S. Gulf Coast, Louisiana State University, Baton Rouge, LA., Oct. 13-15, 1981, pp. 267-272.

10. Brinkman, F.P., "Increased Gas Recovery From a Moderate Water Drive Reservoir," J. Pet Tech. 33, (1981) December 1981.

11. Katz, D.L., et al, Handbook of Natural Gas Engineering, McGraw-Hill Book Co., New York, 1959

12. Eaton Operating Company, Inc., "Fina1 Report G. M. Koelemay Well No. 1., Jefferson County, Texas," Volume II Well Test Data, (DOE/ET/27081-3 Vol. II); Houston. 
APPENDIX

\section{STATIC BOTTOMHOLE PRESSURE}

This procedure relates the fluid volumes produced for a given test period, their respective densities, and shut-in surface pressure readings to a static BHP. In the case of gas, it is assumed that the gas has risen to the top of the production string during a shut-in period and is compressed at the shut-in wellhead pressure. Gas density was determined by assuming a specific gravity of between 0.6 and 0.7 were not stated in reports and by using Figure 4-23, Density of Natural Gases, in the Handbook of Natural Gas Engineering. ${ }^{1}$ The procedure also assumed that pressure does not affect the density of the water or condensate. Water has an assumed density of $62.4 \mathrm{lb} / \mathrm{ft}^{3}$ (1000 $\left.\mathrm{kg} / \mathrm{m}^{3}\right)$. The condensate density is calculated based on the API gravity by first calculating the specific gravity and then converting it to a density.

To obtain a density of the column of fluids for a given set of production test data, a weighted average based on the dally production rates was used. The gas volume was "compressed". from the reported amount at $14.7 \mathrm{psia}(101.4 \mathrm{mPa})$ and $60^{\circ} \mathrm{F}\left(289^{\circ} \mathrm{K}\right)$ to the shutin wellhead pressure at an assumed temperature of $160^{\circ} \mathrm{F}\left(344^{\circ} \mathrm{K}\right)$. Then the adjusted gas volume was converted from cubic feet into barrel equivalents by dividing $5.62 \mathrm{ft}^{3} / \mathrm{bbl}$. The weighted average took into account the ratio of each of the components (gas, condensate, and water) to the total fluid production over a day multiplied by their respective densitities. Adding these weighted values together determined the average colum density, this figure was divided by $144 \mathrm{in}^{2} / \mathrm{ft}^{2}$ to convert density into a pressure gradient of psi/ft of depth. This pressure gradient multiplied by the reservoir depth and added to the shut-in wellhead pressure provided an estimate of the static bottomhole pressure. Dividing the calculated static BHP by the reservolr depth provided an estimate of the pressure gradient of the reservoir.

A test of this procedure to estimate static BHP and the resulting pressure gradient was performed on known data. Previous work by IGT on the Lear-Koelemay Well No. $1^{12}$, a DOE "Well of Opportunity" test, had developed fluid production, shut-in wellhead pressure, and static bottomhole pressure data. Using this computational procedure, an estimate of within 20 psi ' $(.14 \mathrm{MPa})$ at about $9000 \mathrm{psig}(62.1 \mathrm{MPa})$, was obtained when comparing the estimated BHP to that recorded by a quartz crystal BHP sensor. The Lear-Koelemay well was selected because it resembled the producing characteristics of the wells under study.

\section{FLOWING BOTTOMHOLE PRESSURE}

Because much of the publically reported data from periodic well tests does not contain information on shut-in wellhead pressures, the following procedure was used to estimate the bottomhole flowing pressure for those wells of interest. Basically, the addition of the flowing friction drop, the pressure due to the fluid column, and the surface flowing pressure provides the bottomhole flowing pressure or:

BHP (flowing) $=P_{s}+P_{f}+P_{h}$

where $P_{S}=$ Flowing surface pressure (from the production test data)
$P_{f}=$ Friction drop

$P_{h}=$ Pressure due to fluid column

By definition pressure due to flutd column is:

$P_{h}=h \times G_{m}$

where $h=$ depth to mid-perforations

$G_{\mathrm{m}}=$ Fluid mixture pressure gradient

Assuming a uniform rate of production of the fluids, the fluid mlxture pressure gradient is:

$$
G_{m}=\frac{V_{g}}{\left(V_{g}+V_{o}+V_{w}\right)} G_{g}+\frac{V_{o}}{\left(V_{g}+V_{o}+V_{w}\right)} G_{o}+\frac{V_{w}}{\left(V_{g}+V_{o}+V_{w}\right)} G_{w}
$$

where $G_{g}=$ Gas pressure gradient

$G_{0}=011$ (or condensate) pressure gradient

$G_{W}=$ Water pressure gradient

$V_{\dot{g}}=$ Volume of gas at an assumed temperature of $160^{\circ} \mathrm{F}$ and at flowing wellhead pressure in Mcf/day converted to barrel equivalents

$v_{0}=$ Volume of oil (or condensate) in barrels/day

$V_{w}=$ Volume of water in barrels/day

$\mathrm{G}_{\mathrm{g}}=\mathrm{D}_{\mathrm{g}}$ $\frac{8}{144} \mathrm{in}^{2} / \mathrm{ft}^{2}$

where $D_{g}=$ Density of the gas and

$D_{g}=\frac{29 \times \rho_{g} \times\left(P_{s}+14.73\right.}{(14.73) \times\left(460^{\circ}+160^{\circ} \mathrm{F}\right)}$

where $\rho_{g}=$ Specific gravity of gas

$G_{0}=\rho_{0} \times G_{w}$

where $o_{0}=\frac{141.5}{(131.5+\text { API Gravity })}$

$$
\begin{aligned}
& G_{w}=\frac{62.41 \mathrm{~b} / \mathrm{ft}^{3}}{144 \mathrm{in}^{2} / \mathrm{ft}^{2}} \quad \text { or } \\
& G_{w}=0.433 \mathrm{psi} / \mathrm{ft} \quad(9.8 \mathrm{kPa} / \mathrm{m})
\end{aligned}
$$

IGT experience in testing geopressured resources indicates that the pressure gradient for brine is typically less than the $0.465 \mathrm{psi} / \mathrm{ft}(10.5 \mathrm{kPa} / \mathrm{m})$ usually assumed due to the higher temperatures encountered.

The friction pressure loss is estimated by:

$$
\begin{aligned}
& P_{f}= \\
& {\left[\left((1.346)^{-13} \times h \times D_{m}^{0.8275} \times \mu_{m} \times(V g+V o+V w)^{1.8275}\right) /\right.} \\
& \left.\left.r^{4.9597}\right]+\left[(7.392)^{-16} \times{ }^{16} \times D_{m} \times(V g+V o+V w)^{2} / r^{5}\right]\right)
\end{aligned}
$$


where $D_{m}=$ Mixture Density $=G_{m} \times 144 \mathrm{in}^{2} / \mathrm{ft}^{2}$

$$
\mu_{m}=\frac{v_{g} \mu_{g}+v_{o} \mu_{0}+v_{w} \mu_{w}}{\left(v_{g}+v_{0}+v_{w}\right)}
$$

where

$$
\begin{aligned}
\mu_{m}= & \text { viscosity of fluid mixture } \\
\mu_{\mathrm{g}}= & \text { viscosity of gas at } 160^{\circ} \mathrm{F}\left(344^{\circ} \mathrm{K}\right) \\
& \text { assumed to be } 0.02 \mathrm{cP}\left(2 \times 10^{-5} \mathrm{~Pa} \cdot \mathrm{s}\right)
\end{aligned}
$$

$\mu_{0}=$ viscosity of oil or condensate at $160^{\circ} \mathrm{F}\left(344^{\circ} \mathrm{K}\right)$ assumed to be $0.9 \mathrm{cP}$ $\left.9 \times 10^{-4} \mathrm{~Pa} \cdot \mathrm{s}\right)$

$\mu_{W}=$ viscosity of water at $160^{\circ} \mathrm{F}\left(344^{\circ} \mathrm{K}\right)$ assumed to be $0.39 \mathrm{cP}\left(3.98 \times 10^{-4} \mathrm{~Pa} . \mathrm{s}\right)$

$r=$ Internal radius of production tubing. in feet

Because different diameters of tubing are used, the procedure examines two typical diameters: $1.995 \mathrm{in.}\left(2-3 / 8\right.$ in $\left.0 . D_{.}\right)$and $2.441 \mathrm{in.}(2-7 / 8$ in 0.D.)

This procedure was checked against example problems in the Handbook of Natural Gas Engineering ${ }^{11}$ (page 311) and found to yield 1dentical results.

Table 1. CRITERIA FOR TEST SEARCH FOR WATERED-OUT GAS WELLS

\section{SEARCH AREAS}

\section{Vermillion Parish}

St. Mary's Parish

Depth

Pressure

Production

$$
\begin{aligned}
& \text { Latitude } \\
& \text { Longltude }
\end{aligned}
$$

Latitude Longitude

Deeper than $12,000 \mathrm{ft}(3658 \mathrm{~m})$

original pressure with gradient greater than $0.75 \mathrm{psi} / \mathrm{ft}(17.0 \mathrm{k} \mathrm{Pa} / \mathrm{m})$. Final pressure with gradient greater than 0.50 $\mathrm{psi} / \mathrm{ft}(11.3 \mathrm{k} \mathrm{Pa} / \mathrm{m})$

Horizons that were past gas producers (greater than 1 Bcf $\left(2.83 \times 10^{7} \mathrm{~m}^{3}\right.$ ), but are not not producers
Table 2. LOUISIANA FIELDS HAVING THREE OR MORE POTENTIAL CANDIDATE WELLS

Bon Air

Cameron

Church Point

Deep Lake

Fresh Water Bayou, North Garden City

Gibson

Golden Meadow

Grand Chenfere

Hollywood

Jennings, South

Judice

Lac Blanc

Lake Arthur

Lake Barre

Lake Raccourci

Lake Verret, West

Lawson

Little Pecan Lake

Live Oak

Manchester

Manchester, South

Midland

Patterson

Pecan Lake, South

Pointeala Hache

Raceland

Rayne

Rousseau

Sunrise, South

Thibodaux

Thornwe11, South

Table 3. TEXAS FIELDS HAVING THREE OR MORE POTENTIAL CANDIDATE WELLS

$\begin{array}{ll}\text { Alazan, North } & \text { Laguna Larga } \\ \text { Borregas } & \text { Panther Reef } \\ \text { Cook, South } & \text { Seellgsoa } \\ \text { Encinal Channel } & \text { Sheridan (Wilcox) } \\ \text { High Island Block } 14 & \text { Viboras } \\ \text { Katy } & \text { Yorktown } \\ \text { Lagloria } & \text { Zone 21B, Trend \#6 }\end{array}$


Table 5. TEXAS FIELDS RECOMMENDED FOR FURTHER STUDY AND POSSIBLE ENHANCED GAS RECOVERY

Table 4. LOUISIANA FIELDS RECOMMENDED AS CANDIDATES FOR ENHANCED GAS RECOVERY

$\begin{array}{lll}\text { Field } & \text { Parish } & \text { Operator } \\ \text { Garden City } & \text { St. Mary } & \text { Quintana } \\ \text { Gibson } & \text { Terrebonne } & \text { Pennzoil } \\ \text { Chalkley, North } & \text { Calcasieu } & \text { Sun } \\ \text { Manchester, South } & \text { Calcasieu } & \text { W.E. Walker } \\ \text { Midland } & \text { Acadia } & \text { Arco } \\ \text { Six Mile Lake } & \text { Calcasieu } & \text { Gulf Oil } \\ \text { Lacassine Refuge } & \text { Cameron } & \text { Sun Exploration } \\ \text { Thibodaux, North } & \text { Lafourche } & \text { Amoco } \\ \text { Lake Verret, West } & \text { Lberia } & \text { Shell oil } \\ \text { Lake Arthur } . & \text { Jefferson Davis } & \text { Chevron }\end{array}$

$\begin{array}{lll}\text { Field } & \text { County } & \text { Operator } \\ \text { Martin Ranch } & \text { Brazoria } & \text { Mobil } \\ \text { Alta Loma, East } & \text { Galveston } & \text { Phillips } \\ \text { Devillier } & \text { Chambers } & \text { Gulf oil } \\ \text { Maude B. Traylor, North } & \text { Calhoun } & \text { Superior o1l } \\ \text { Viboras (Massive First) } & \text { Brooks } & \text { Exxon } \\ \text { Chocolate Bayou } & \text { Brazoria } & \text { Phillips } \\ \text { Chesterville } & \text { Colorado } & \text { Mobil } \\ \text { Sugar Valley } & \text { Matagordo } & \text { Superior oil } \\ \text { La Gloria } & \text { Brooks } & \text { Mobil } \\ \text { Trinity Bay } & \text { Chambers } & \text { Exxon } \\ \text { Seelingson } & \text { Jim Wells } & \text { Sun } \\ \text { Miller Grove } & \text { Chambers } & \text { Watson Oil } \\ \text { Calandria } & \text { Jim Wells } & \text { Exxon }\end{array}$
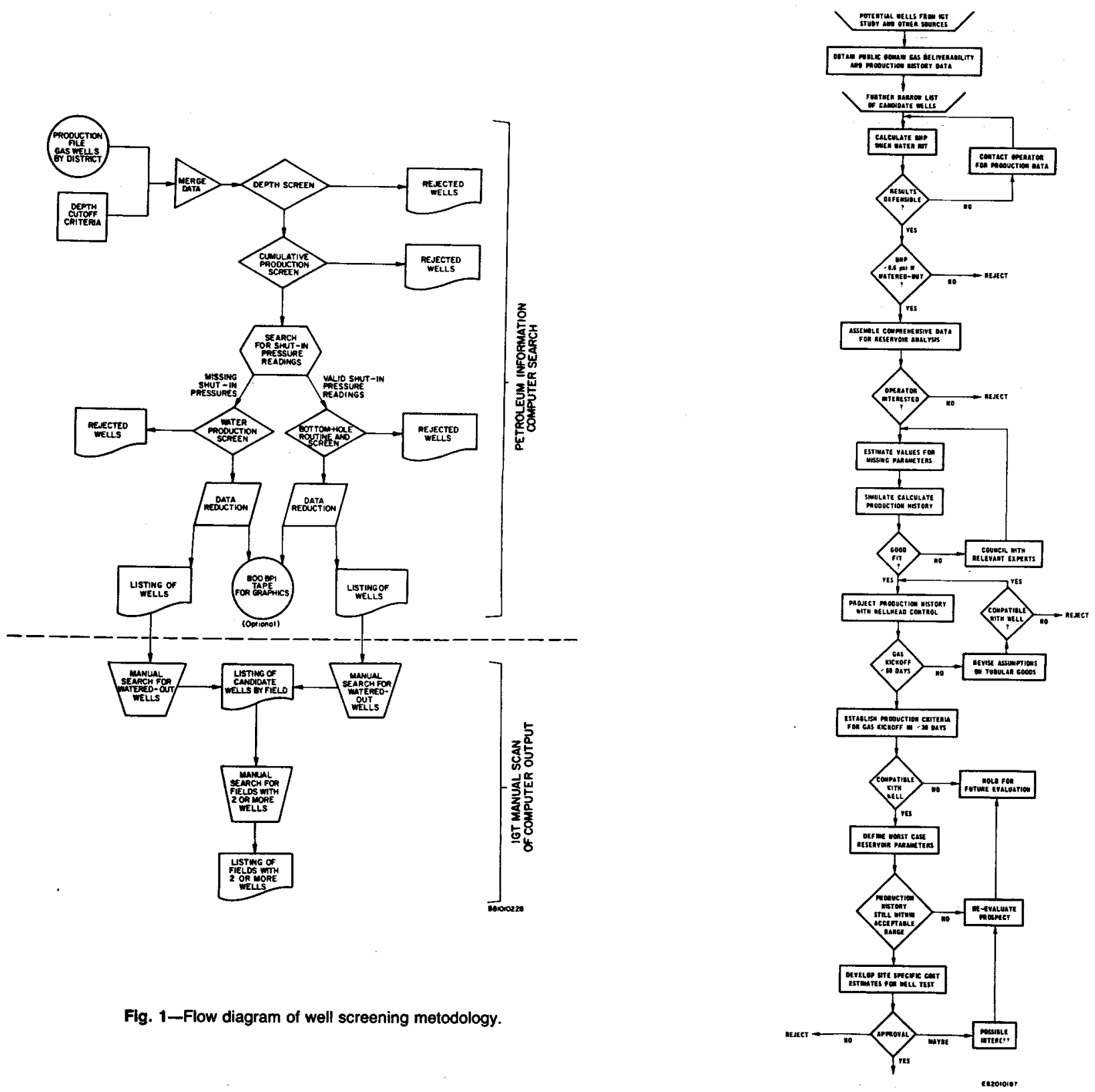

Fig. 1-Flow diagram of well screening metodology.

Fig. 2-Enhanced gas recovery prospect qualification process. 